\title{
Plant for cleaning oils from oxidation products
}

\author{
Nargiza Kholikova ${ }^{1}$, Bakhodir Khakimov $^{1 *}$, Saydilla ${ }^{1}$ Alikulov, Nargiza Ravshanova ${ }^{2}$ and \\ Ajargul Mambetsheripova ${ }^{3}$ \\ ${ }^{1}$ Tashkent institute of irrigation and agricultural mechanization engineers, Tashkent, Uzbekistan \\ ${ }^{2}$ Karshi Engineering-Economic Institute, Karshi, Uzbekistan \\ ${ }^{3}$ Karakalpak State University, Nukus, Uzbekistan
}

\begin{abstract}
The study aims to substantiate the parameters and operating mode of the oil purification device from oxidation products to improve the efficiency of the use of lubricants. The methods of mathematical analysis and mathematical statistics, comparative comparison, generalization, and testing methods of agricultural machinery are used in the research process. It is established that engine oils are intensively polluted by oxidation products during processing, thereby accelerating the friction process due to the overload of tractor engines. During the performance of agricultural work in the oil composition, the content of oxidation products in the form of carbon, carbon dioxide, and asphalt products increases by $1.2 \%$. Analytical coupling dependences for the process of cleaning motor oils from oxidizing products are obtained, and the dependence of the cleaning efficiency on the device parameters is established. The developed device consists of a container for collecting oils, a steam generator, a container for a sump mixer, a separate container for pure and sedimentary oils, and a vessel for re-collecting acetone. An installation has been developed to implement the technology of collecting and renewing oils in the conditions of the farm. In this case, the amount of contamination and the composition of oils is determined, and the operating mode of the device is selected for their resumption.
\end{abstract}

\section{Introduction}

In the Republic of Uzbekistan, targeted research works are being carried out aimed at creating energy-saving technical means for tillage [1-21], sowing [22-23], harvesting [24], and processing [25] of agricultural crops. The main goal of the development of energysaving technical means is to reduce the cost of fuel and lubricants. The yield and cost of production in agriculture largely depend on the consumption and timely provision of fuel and lubricants to tractors and other means. Due to the lack of fuel and lubricants in agriculture, the deadlines for work are violated [26-27].

In world practice, various devices have been developed for the effective recovery process of used oils. Research on the creation of devices to clean used oils, the justification

\footnotetext{
* Corresponding author: bahodir.1978@mail.ru
} 
of technological processes and parameters, and also for improving them engaged in K.Rybakov [28-29], Yu.Usanov [28], V.Kovalenko [29], A. Smirnov [30], N.Kirichenko [31], Gnatchenko I. [32] Z.Alimova [33] V. Danilov [34], V.Dzherihov [35], A.Magerramov [36], R.Ahmedova [37] L.Nagorskaya [38], T.Sharipov [39], N.Kholikov [39] and others.

The devices created as a result of these studies are used in agriculture, and in this direction, positive results have been achieved to a certain extent. However, in these studies mentioned above, the tasks of developing a device that completely cleans used oils and justifying the parameters of working parts that ensure its high quality are not sufficiently studied.

\section{Methods}

As an alternative, a device based on a selective method for removing motor oils from oxidation products and the principle of its operation is provided [40].

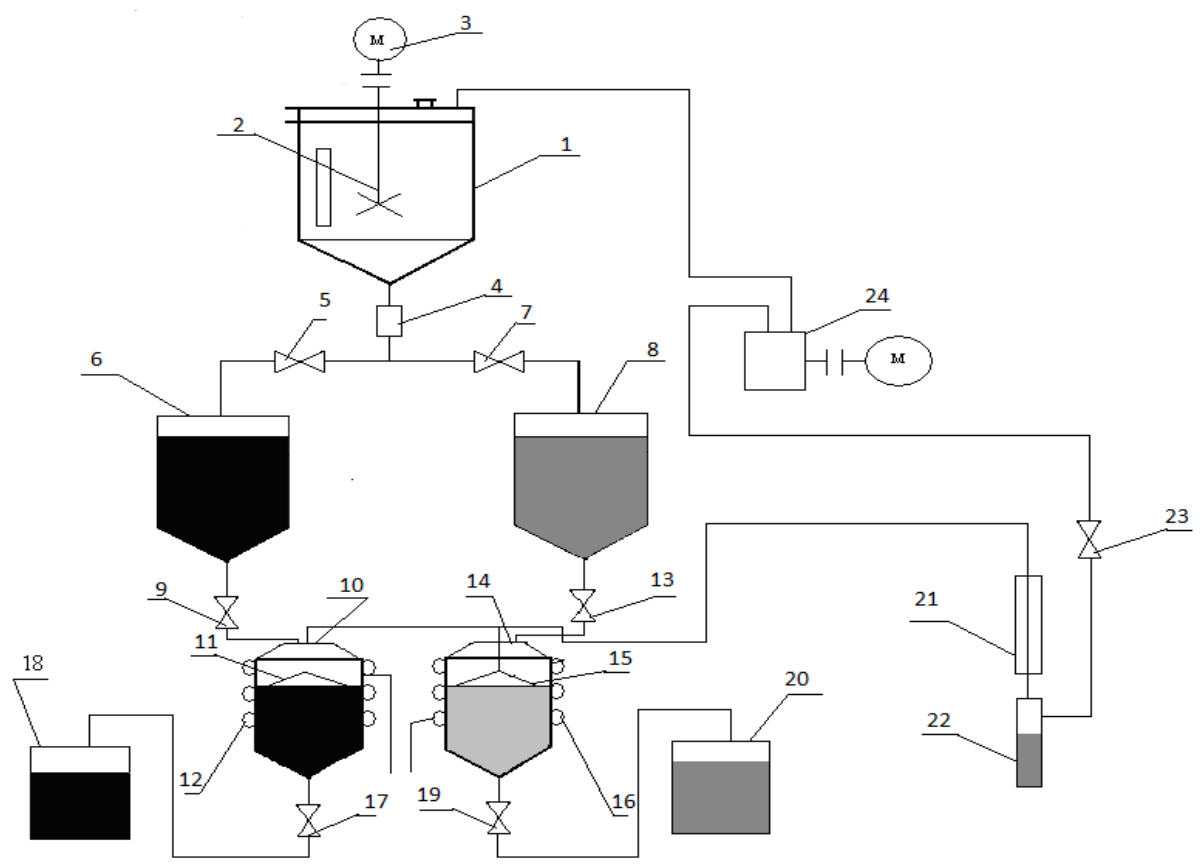

Fig. 1. General view of the stand for cleaning motor oils from oxidation products: 1 is tank; 2 is mixer-sump; 3 is engine; 4 is viewing window; 5 and 7 are cranes; 6 and 8 are containers for collecting contaminated and purified oil; 9 and 13 are taps; 10 and 14 are containers for evaporating solvent; 11 and 15 are evaporator plates with electric heating; 12 and 16 are spirals; 17 and 19 are taps; 18 and 20 are containers for collecting contaminated and purified oil; 21 is refrigerator; 22 is condensate; 23 is tap; 24 is pump.

The installation works in the following order: the waste oil is poured into the container together with the acetone solvent. The solution in the container is mixed with a propeller mixer for 12 minutes, then settled for 23 minutes. Then, based on the testimony of the viewing window with cranes is divided into tanks cleaned and dirty oils through evaporation dishes is evaporated acetone, and then divided into the tank cleaned and the dirty oils. 
Laboratory and operational studies carried out with the help of the proposed installation showed a change in the oil properties when using selective solvents.

Prepare a cleaning agent for the oxidizing products of oils used for containers, mixers, disintegrating devices, and containers for purified oils and solvents for mixing with an oilsoluble compound.

\section{Results and Discussion}

To assess the degree of purification, an analysis of the properties of the engine oil was used. The results of the selective deletion process are shown below. It has been shown that in oil purification studies, when the mixture temperature is $180 \mathrm{C}$, the effectiveness of acetone and a variety of engine oils is improved by increasing the acetone content in the oil. The maximum cleaning efficiency is expected to be 35-40 minutes for the mixture. If the ratio of acetone to oil is $80 \%, 60 \%$, and $40 \%$, cooling can be achieved within 35 minutes. Also, cooling can be achieved within 40 minutes if the ratio of acetone to oil is $80 \%, 60 \%$, and $40 \%$.

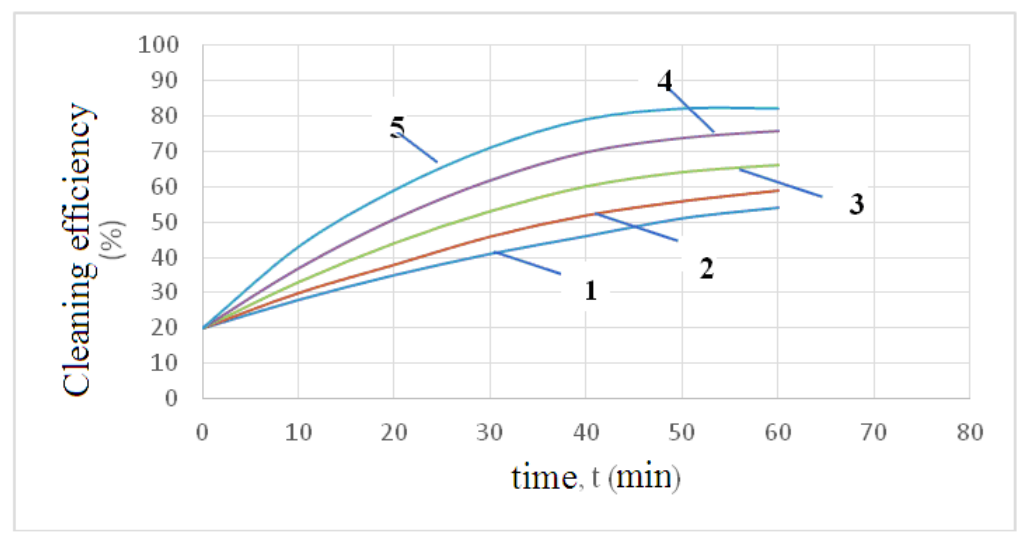

Fig. 2. Graphs of the lubrication efficiency $\left(\mathrm{T}=27^{\circ} \mathrm{C}\right)$ as a function of the settling time at different ratios of acetone and oil: 1 -acetone $80 \%+$ oil $20 \%$, 2-acetone $60 \%+$ oil $40 \%$, 3-acetone $50 \%+$ oil $50 \%$, 4-acetone $40 \%+$ oil $60 \%$, 5-acetone $20 \%+$ oil $80 \%$

Studies on the cooling of oils used in different proportions of acetone and engine oil when heating the mixture at a temperature of $27^{\circ} \mathrm{C}$ have shown that the efficiency of oil purification improves with the percentage of acetone in the oil. If the ratio of acetone to oil is $80 \%, 60 \%$, and $40 \%$, cooling can be achieved within 25 minutes. Cooling can be achieved within 30 minutes if the ratio of acetone to oil is $80 \%, 60 \%$, and $40 \%$.

The maximum cleaning effect is 20-25 minutes of cooling if the mixture's temperature is $50{ }^{\circ} \mathrm{C}$. Also, cooling can be achieved within 20 minutes if the ratio of acetone to oil is $80 \%, 60 \%$, and $40 \%$.

Except for the transparency of the purified oil, all indicators meet the requirements. One of the main reasons for the low transparency of the cooled refined oils is the difficulty of separating the strongly bound organic matter in the oil. It is advisable to mix it with a longlasting solvent to remove all organic matter from the oil. According to many scientists, this indicator does not significantly affect the process of engine friction. Indicators for comparing the physical and chemical properties of the used and purified oils are shown in Table 1. 
Table 1. Indication of comparison of physical and chemical properties of used and purified oils

\begin{tabular}{|c|c|c|c|c|}
\hline \multirow{2}{*}{ № } & Name of impurities & Used oil & Purified oil (50:50) & GOST \\
& & & & \\
\hline 1 & Content of mechanical impurities, \% & 0.45105 & 0.014 & 0.015 \\
\hline 2 & Kinematic viscosity, cSt & 9.9 & 8.92 & 8.0 \\
\hline 3 & Acid number, mg KOH/g & 6.13 & 1.65 & 2.0 \\
\hline 4 & Base number, mg KOH/g & 2 & 4.7 & 6.5 \\
\hline 5 & Color & Above 8 & 3 & 2 \\
\hline
\end{tabular}

The data are given in Table 1 confirm the influence of the engine oil cleaner. According to our research, the indicators of the purified oil are close to GOST.

The best chromaticity result for oils $(\mathrm{P}=2.4)$ was at a temperature of $50^{\circ} \mathrm{C}$, a cooling time of 60 minutes and a mixture ratio reduced to 50: 50, and the contamination concentration was $0.22 \%$.

With a high concentration of mechanical compositions, the color of the oil disappears as the oil temperature increases. From a physical point of view, this can be explained by the fact that when the temperature of the solution increases, the light fractions of acetone evaporate, which, in turn, reduces the capacity of the acetone resin.

An increase in temperature has a positive effect on cooling. At $T=50{ }^{\circ} \mathrm{C}$, when the cooling time is 23 minutes, and the concentration of mechanical mixtures is 50:50, and the ratio $X=0.08-0.15 \%$, the oil color $P=2.4$.

Thus, high chrome is obtained in the following operating modes:

- mixture ratio - by volume

- Oil temperature

50:50;

- settling time

$50{ }^{\circ} \mathrm{C}$;

- concentration of mechanical mixtures

23 minutes;

$0.08-0.15 \%$.

Performance testing of oxidation products used motor oil, developed by the author with oil purifier brands ITAC (PWAM)-100 was conducted at agricultural enterprises yukori Chirchik district of Tashkent region following the methodology set out in Chapter 3. The purpose of the performance test was to establish the operational life of the device. At the same time, the filters were periodically regenerated and re-tested after each resource cycle. The content of organic contamination was determined by the color and acid content.

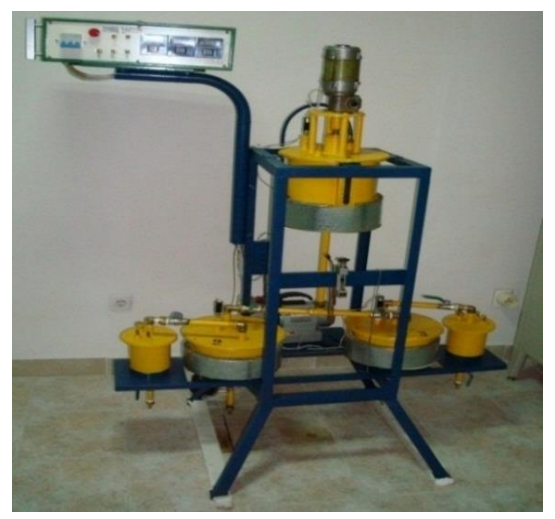

Fig. 3. General view of the experimental oil treatment plant: 1 is mixer-sump, 2 is engine; 3 is tank; 4 is sensor; 5 is rack; 6 is spiral. 
Studies have shown that the mass contamination of refined oil decreased by about 3-4 times the amount of pollutants in the oil sample. The experimental results of the operating mode of the device are shown in Table 2.

Table 2. Experimental results of the device operation mode

\begin{tabular}{|c|c|}
\hline - oil pressure, $\mathrm{MPa}$ & $0.6-0.64$ \\
\hline - oil temperature, ${ }^{\circ} \mathrm{C}$ & 80 \\
\hline - the linear velocity of the oil flow along the filter, $\mathrm{m} / \mathrm{s}$ & 16 \\
\hline - ratio of oil to acetone & $50: 50$ \\
\hline - heating temperature in the evaporation device, ${ }^{\circ} \mathrm{C}$ & 53 \\
\hline - mixing time, minutes & 12 \\
\hline - settling time, minutes & 23 \\
\hline - the ratio of refined and new oil & $50: 50$ \\
\hline
\end{tabular}

For the experiments, 1.2 percent oil was selected, which contains most of the organic ingredients. In this case, the flash point was $165^{\circ} \mathrm{C}$, and the kinematic viscosity was: 6.82 $\mathrm{mm} 2 / \mathrm{s}$ at $100^{\circ} \mathrm{C}$. As shown in Table 3 , the refined oil parameters meet the standard requirements.

Table 3. Physical and chemical characteristics of refined engine oil M-10 G2

\begin{tabular}{|c|c|c|c|c|}
\hline № & Indicators & Used oil & $\begin{array}{c}\text { Requirement for } \\
\text { refined oil standards }\end{array}$ & Purified oil \\
\hline 1. & Kinematic viscosity, cSt & 6.82 & $11+0.5$ & 9.1 \\
\hline 2. & $\begin{array}{c}\text { Content of mechanical } \\
\text { mixtures, \% }\end{array}$ & 0.456 & 0.015 & 0.006 \\
\hline 3. & Water content, \% & 0.21 & Footprints & Footprints \\
\hline 4. & $\begin{array}{c}\text { Content of asphalt and } \\
\text { resin compounds, \% }\end{array}$ & 0.48 & 0.29 & Footprints \\
\hline 5. & Ash content \% & 1.8 & 1.65 & 1.42 \\
\hline 6. & Base number & 2.77 & 6 & 4.7 \\
\hline 7. & $\begin{array}{c}\text { Flash point of the open } \\
\text { crucible, } \mathrm{C}^{\mathrm{o}}\end{array}$ & 165 & 205 & 207 \\
\hline 8. & Content of the fuel, \% & 6.3 & 0.8 & 0.5 \\
\hline
\end{tabular}

The test of engine oils from oxidation products was carried out on the D-243 engine of the tractor TTZ-811.

Experience has shown that the change in the content of butyric acids in engine oils used in the process of cleaning engine oil during 250 moto-hours practically does not differ from the content of alkaline oil, and their resource is $82 \%$.

\section{Conclusions}

1. It is established that engine oils are intensively polluted by oxidation products during processing, thereby accelerating the friction process. Due to the overload of tractor engines, during agricultural work, the content of oxidation products in the form of carbon carbene, carboid, and asphalt products in the oil composition increases by $1.2 \%$.

2. Analytical coupling dependences for the process of cleaning motor oils from oxidizing products are obtained, and the dependence of the cleaning efficiency on the device 
parameters is established. The developed device consists of a container for collecting oils, a steam generator, a container for a sump mixer, a separate container for pure and sedimentary oils, and a vessel for re-collecting acetone.

3. An installation has been developed to implement the technology of collecting and renewing oils in the conditions of the farm. In this case, the amount of contamination and the composition of oils is determined, and the operating mode of the device is selected for their resumption.

\section{References}

1. Mamatov, F.M., Eshdavlatov, E., Suyunov, A. The Shape of the Mixing Chamber of the Continuous Mixer // Jour of Adv Research in Dynamical \& Control Systems, Vol. 12, 07-Special Issue, 2020. DOI: 10.5373/JARDCS/V12SP7/20202318 ISSN 1943$023 \mathrm{X}$.

2. Mamatov, F., Ergashev, I., Ochilov, S., Pardaev, X. Traction Resistance of Soil Submersibility Type "Paraplau" // Jour of Adv Research in Dynamical \& Control Systems, Vol.12, 07-Special Issue, 2020. DOI: 10.5373/JARDCS/V12SP7/20202336 ISSN1943-023X.

3. Aldoshin, N., Mamatov, F., Ismailov, I., Ergashov, G. Development of combined tillage tool for melon cultivation // 19th international scientific conference engineering for rural development Proceedings, Jelgava, 20.-22.05.2020. Volume 19. ISSN 16915976. DOI:10.22616/ERDev.2020.19.TF175.

4. Umurzakov, U., Mirzaev, B., Mamatov, F., Ravshanov, H., Kurbonov, S. A rationale of broach-plow's parameters of the ridge-stepped ploughing of slopes // XII International Scientific Conference on Agricultural Machinery Industry IOP Conf. Series: Earth and Environmental Science 403(2019) 012163 IOP Publishing doi:10.1088/1755-1315/403/1/012163.

5. Mirzaev, B., Mamatov, F., Chuyanov, D., Ravshanov, X., Shodmonov, G., Tavashov, R and Fayzullayev, X. Combined machine for preparing soil for cropping of melons and gourds // XII International Scientific Conference on Agricultural Machinery Industry. doi.org/10.1088/1755-1315/403/1/012158.

6. Mirzaev, B., Mamatov, F., Ergashev, I., Ravshanov, H., Mirzaxodjaev, Sh., Kurbanov, Sh., Kodirov, U and Ergashev, G. Effect of fragmentation and pacing at spot ploughing on dry soils // E3S Web of Conferences 97. doi.org/10.1051/e3sconf/201913501065.

7. Mamatov, F., Mirzaev, B., Shoumarova, M., Berdimuratov, P., Khodzhaev, D. Comb former parameters for a cotton seeder// International Journal of Engineering and Advanced Technology (IJEAT) Volume-9 Issue1 October/ DOI: 10.35940/ijeat.A2932.109119.

8. Mamatov, F., Mirzaev, B., Batirov, Z., Toshtemirov, S., Tursunov, O., Bobojonov, L. Justification of machine parameters for ridge forming with simultaneous application of fertilizers // CONMECHYDRO - 2020 IOP Conf. Series: Materials Science and Engineering 883(2020) 012165 IOP Publishing. doi:10.1088/1757899X/883/1/012165.

9. Mirzaev, B., Mamatov, F., Avazov, I., Mardonov, S. Technologies and technical means for anti-erosion differentiated soil treatment system // E3S Web of Conferences. doi.org/10.1051/e3sconf/20199705036.

10. Aldoshin, N., Didmanidze, O., Mirzayev, B., Mamatov, F. Harvesting of mixed crops by axial rotary combines // Proceeding of $7^{\text {th }}$ International Conference on Trends in Agricultural Engineering 2019. $17^{\text {th }}-20^{\text {th }}$ Prague, Czech Republic. - pp.20-26. 
September (2019).

11. Mirzaev, B., Mamatov, F., Aldoshin, N and Amonov, M. Anti-erosion two-stage tillage by ripper// Proceeding of 7 th International Conference on Trends in Agricultural Engineering 17th-20th. Prague, Czech Republic. - pp.391-396. September (2019).

12. Mirzaev, B., Mamatov, F., Ergashev, I., Islomov, Yo., Toshtemirov, B., Tursunov O. Restoring degraded rangelands in Uzbekistan // Procedia Environmental Science, № 6. - pp 395-404. (2019).

13. Uzakov, Z.U., Mamatov, F.M., Begulov, O. Implementation of object-oriented Programming technology in the one-dimensional oil displacement problem // International Conference on information Science and Communications Technologies: ICISCT 2019/0012008. Tashkent, Uzbekistan. INSPEC Accession Number: 19412491. DOI: 10.1109/ICISCT47635.2019.9012008.

14. Mamatov, F., Mirzaev, B., Berdimuratov, P., Turkmenov, Kh., Muratov, L., Eshchanova, G. The stability stroke of cotton seeder moulder // CONMECHYDRO 2020. IOP Conf. Series: Materials Science and Engineering 883 (2020) 012145 IOP Publishing. doi:10.1088/1757-899X/883/1/012145.

15. Mamatov, F., Mirzaev, B., Tursunov, O. A Justification of Broach-Plow's Parameters of the Ridge-Stepped Ploughing // E3S Web of Conferences 97, 05035 (2019). doi.org/10.1051/e3sconf/20199705035.

16. Ahmedov, B.J., Mirzaev, B.S.,Mamatov, F.M., Khodzhaev, D.A., Julliev, M.K. Integrating of gis and gps for ionospheric perturbations in d- And f-layers using vlf receiver // InterCarto, InterGIS 26, - c. 547-560. DOI: 10.35595/2414-9179-2020-126-547-560.

17. Mamatov, F., Mirzaev, B., Tursunov, O., Ochilov, S and Chorieva, D. Relief, physicomechanical and technological properties of soil in the cotton growing area // ICECAE 2020. IOP Conf. Series: Earth and Environmental Science 614(2020) 012169. IOP Publishing. doi:10.1088/1755-1315/614/1/012169.

18. Shamsutdinov, Z., Ubaydullaev, Sh., Shamsutdinov, N., Mirzaev, B., Mamatov, F., and Chorshabiyev, N. The concept of the phytogenic field: theory, research experience and practical significance // ICECAE 2020. IOP Conf. Series: Earth and Environmental Science 614(2020) 012164. IOP Publishing. doi:10.1088/17551315/614/1/012164.

19. Umurzakov, U., Mamatov, F., Aldoshin, N., and Mirzaev, B. Exploration of tillage technologies in the Republic of Uzbekistan // ICECAE 2020 IOP Conf. Series: Earth and Environmental Science 614(2020) 012168. IOP Publishing. doi:10.1088/1755$1315 / 614 / 1 / 012168$.

20. Mamatov, F., Aldoshin, N., Mirzaev, B., Ravshanov, H., Kurbanov, Sh and Rashidov, N. Development of a frontal plow for smooth, furless plowing with cutoffs // IPICSE 2020. IOP Conf. Series: Materials Science and Engineering 1030 (2021) 012135 IOP Publishing. doi:10.1088/1757-899X/1030/1/012135.

21. Mamatov, F., Mirzaev, B., Mirzahodzhaev, Sh., Uzakov, Z and Choriyeva, D. Development of a front plow with active and passive working bodies // IPICSE 2020. IOP Conf. Series: Materials Science and Engineering 1030 (2021) 012164. IOP Publishing. doi:10.1088/1757-899X/1030/1/012164.

22. Mamato, F.M., Eshdavlatov, E., Suyuno, A. Continuous Feed Mixer Performance //Journal of Advanced Research in Dynamical and Control Systems (JARDCS). Volume-12, 07-Spesial Issue, (2020). DOI: 10.5373/JARDCS/V12SP7/20202343. ISSN 1943-023X.

23. Mamatov, F., Ergashev, I., Mirzaev, B., Pardaev, X, Chorieva, D. Research of the Penetration Process of the Frontal Plow // 2nd Bukittinggi International Conference on 
Education (BICED) 2020. Journal of Physics: Conference Series 1779 (2021) 012002. IOP Publishing. doi:10.1088/1742-6596/1779/1/012002.

24. Rybakov K.V, Usanov Ju.A. Rabota polnopotochnyh ochistitelej masla // Tehnika v sel. hoz-ve. - № 2. - pp.24-26. [In Russian]. (1987).

25. Rybakov K.V., Kovalenko V.P, Andreev S.P. Zagrjaznennost' nefteproduktov: problemy i predlozhenija // Mehanizacija i jelektrifikacija sel. hoz-va. - № 9. - pp. 37 38. [In Russian]. (1989).

26. Smirnov A. V. Avtomobil'nye jeksplutacionnye materialy: uchebnoe posobie. Velikij Novgorod: NovGU, -p. 176. [In Russian]. (2004).

27. Kirichenko N.B. Avtomobil'nye jekspluatacionnye materialy // Uchebnoe posobie dlja sred.prof.obrazovanija - M.: Iz.Centr «Akademija», [In Russian]. (2012).

28. Gnatchenko I.I. i dr. Avtomobil'nye masla, smazki, prisadki: Spravochnoe posobie. M.: OOO «Izdatel'stvo AST»; -p. 360. [In Russian]. (2000).

29. Alimova Z.H. Puti uluchshenija svojstv smazochnyh materialov primenjaemyh v transportnyh sredstvah. Monografija -T.:«Vneshinvestrom»,-p. 125. [In Russian]. (2020).

30. Danilov V.F. i dr. Masla, smazki i special'nye zhidkosti. Uchebnoe posobie // Elabuga: izd-vo filiala K (P) FU. - p. 216. [In Russian]. (2013).

31. Dzherihov V. B. Avtomobil'nye jekspluatacionnye materialy: uchebnoe posobie // Sankt-Peterburg: SPGASU, -p. 256. [In Russian]. (2009).

32. Magerramov A.M., Ahmedova R.A., Ahmedova N.F. Neftehimija I neftepererabotka: Uchebnik dlja vysshih uchebnyh zavedenij. - Baku: Baky Universiteti, -p. 660. [In Russian]. (2009).

33. Reznikov V.D., Sinajskij Je.G., Hurgin Ja.I. Raschet koncentracii nerastvorimyh zagrjaznenij v rabotajushhem dizel'nom masle / // Dvigatelestroenie. - № 8. - pp. 4142. [In Russian]. (1983)

34. Nagorskij L.A., Kachanova L.S. Ocenka jeffektivnosti ochistki otrabotannogo masla centrifugami / // Nauchnaja molodezh'- agropromyshlennomu kompleksu. Zernograd: FGOU VPO AChGAA, 2003. S.181-186. [In Russian].

35. Nagorskij L.A., Kachanova L.S. Ob ocenochnyh pokazateljah separirujushhej sposobnosti centrifug / // Nauchnaja molodezh'-agropromyshlennomu kompleksu. Zernograd: FGOU VPO AChGAA, - pp. 186-190. (2003).

36. Sharipov K.A., Khalikova N.A. Establishing patterns of flow of a viscous fluid on the lateral surface of the rotating cone // European Science Review. № 1-2. - pp.260 262. - Austria, (2018).

37. Marupov, I, Imomov, Sh, Ermatova, D, Majitov,J, Kholikova, N, Tagaev, V, and Nuritov, I. Research of vertical forces for acting tractor unit // ICECAE 2020. IOP Conf. Series: Earth and Environmental Science 614(2020) 012153. IOP Publishing. doi:10.1088/1755-1315/614/1/012153.

38. Alimova, Z, Kholikova, $\mathrm{N}$ and Kholova, S. Improvement of properties of oils used in hydraulic systems of road-construction equipment // CONMECHYDRO - (2020). IOP Conf. Series: Materials Science and Engineering 883(2020) 012167. IOP Publishing. doi:10.1088/1757-899X/883/1/012167.

39. Imomov, Sh, Kholikova, N, Alimova, Z, Nuritov, I, Temirkulova, N. Oil Purification Devices Used in Internal Combustion Engines // International Journal of Innovative Technology and Exploring Engineering (IJITEE), (2019) 